\title{
Functional Results of Surgery for Otosclerosis
}

\author{
Otoskleroz Cerrahisi Fonksiyonel Sonuçları
}

\author{
(1) Deniz Tuna Edizer, (1) Müge Fethiye Yürekli Altındağ, (1) Özgür Yiğit, (1) Ahmet Görkem Yasak
}

istanbul Training and Research Hospital, Clinic of Otolaryngology, i̇stanbul, Turkey

\begin{abstract}
Introduction: To evaluate the audiological variables and to investigate the factors affecting hearing improvement in patients who underwent stapedotomy with the diagnosis of otosclerosis.

Methods: The data of 114 patients who had middle ear exploration were retrospectively reviewed. Air conduction thresholds between 250-6000 $\mathrm{Hz}$ and bone conduction thresholds between $500-4000 \mathrm{~Hz}$ were examined in pure tone audiometry. Postoperative air-bone gap (ABG), change in $A B G$, and change in bone conduction threshold at high frequency were primarily examined. The results of different piston diameters were compared.

Results: Eighty-three patients with stapedial footplate fixation were included in the study. While post-operative air conduction thresholds decreased significantly at all frequencies, bone conduction thresholds decreased significantly only at 2000 $\mathrm{Hz}(\mathrm{p}=0.001)$. The most notable gain in $\mathrm{ABG}$ was obtained at $500 \mathrm{~Hz}$. The post-operative air conduction pure tone average was significantly higher in patients with $0.6 \mathrm{~mm}$ diameter prosthesis. Postoperative mean ABG and ABG values at 2000 and $4000 \mathrm{~Hz}$ were found to be significantly lower in patients with $0.8 \mathrm{~mm}$ diameter prosthesis $(p<0.05)$. The change in ABG at $2000 \mathrm{~Hz}$ was significantly lower in patients with 0.6 $\mathrm{mm}$ diameter prosthesis $(\mathrm{p}=0.029)$. The mean change in bone conduction thresholds at high frequencies was positive in 58 patients (70\%) and negative in 25 patients (30\%). There was no difference between different piston diameters regarding bone thresholds at high frequencies.

Conclusion: Improvement was achieved at all frequencies in air conduction thresholds following stapedotomy. In our study, it was found that the lower the pre-operative bone conduction thresholds were, the more the improvement in ABG. A significant advantage was achieved at 2000 and $4000 \mathrm{~Hz}$ frequencies in patients with $0.8 \mathrm{~mm}$ piston diameter compared to $0.6 \mathrm{~mm}$ piston diameter.
\end{abstract}

Keywords: Air-bone gap, otosclerosis, stapedotomy

\section{öz}

Amaç: Otoskleroz tanısıyla stapedotomi yapılmış olan olgularda odyolojik değișkenleri değerlendirmek ve işitme kazancını etkileyen faktörleri incelemektir.

Yöntemler: Orta kulak eksplorasyonu yapılmış 114 hastanın retrospektif taraması yapıldı. Saf ses odyometrik incelemede hava iletim eșikleri 250-6000 Hz arası, kemik iletim eșikleri ise $500-4000 \mathrm{~Hz}$ arasında incelendi. Postoperatif hava-kemik aralığı (HKA), HKA değerindeki değișim ve yüksek frekans kemik iletimindeki değișim primer olarak incelendi. Farklı çapta piston kullanılan hastaların sonuçları kıyaslandı.

Bulgular: Stapes taban fiksasyonu tespit edilen 83 hasta çalışmaya dahil edildi. Postoperatif hava yolu eșiklerinde tüm frekanslarda anlamlı azalma tespit edilirken, kemik yolu eșiklerinde sadece 2000 Hz'te anlamlı bir azalma tespit edildi $(p=0,001)$. HKA'da en yüksek kazanç $500 \mathrm{~Hz}$ 'te elde edildi. Postoperatif hava yolu saf ses ortalaması $0,6 \mathrm{~mm}$ çaplı protez kullanılan hastalarda anlamlı olarak daha yüksek tespit edildi. Postoperatif HKA ortalaması ile 2000 ve 4000 Hz'teki değerleri, 0,8 mm piston çapı kullanılan hastalarda anlamlı olarak daha düşük bulundu $(p<0,05)$. HKA değişimi $2000 \mathrm{~Hz}$ te $0,6 \mathrm{~mm}$ çaplı piston kullanılan hastalarda anlamlı olarak daha düşük idi $(p=0,029)$. Yüksek frekans kemik eșikleri ortalamasındaki değișim 58 hastada (\%70) pozitif iken, 25 hastada (\%30) negatif değerdeydi. Farklı piston çapları arasında yüksek frekans kemik eșikleri açısından fark saptanmadı.

Sonuç: Stapedotomi sonrasında hava yolu eşiklerinde tüm frekanslarda kazanç sağlanmıştır. Çalışmamızda, preoperatif kemik yolu eșikleri ne kadar düșükse, HKA kazancının o kadar fazla olduğu tespit edilmiştir. 0,8 mm çaplı piston kullanılanlarda, 0,6 mm çaplı piston kullanılan hastalara göre 2000 ve 4000 Hz'te anlamlı avantaj elde edilmiştir.

Anahtar Kelimeler: Hava-kemik aralığı, otoskleroz, stapedotomi
Address for Correspondence/Yazıșma Adresi: Deniz Tuna Edizer, İstanbul Training and Research Hospital, Clinic of Otolaryngology, İstanbul, Turkey

E-mail: deniztunaedizer@yahoo.com ORCID ID: orcid.org/0000-0003-4448-1881

Cite this article as/Atıf: Edizer DT, Yürekli Altındağ MF, Yiğit Ö, Yasak AG. Functional Results of Surgery for Otosclerosis. İstanbul Med J 2019; 20(1): 21-5.
Received/Geliș Tarihi: 05.01.2017 Accepted/Kabul Tarihi: 04.02.2018

(C) Copyright 2019 by the Istanbul Training and Research Hospital/istanbul Medical Journal published by Galenos Publishing House.

(C)Telif Hakkı 2019 Istanbul Ĕgitim ve Araștırma Hastanesi/Istanbul Tıp Dergisi, Galenos Yayınevi tarafından basılmıștır. 


\section{Introduction}

Otosclerosis is an otic capsule disease characterized by bone resorption and replacement that causes fixation in the stapes footplate (1). Otosclerosis, which is one of the common causes of conductive hearing loss in adults, is seen more frequently in women and between the ages of 30-40 years (2). Two-thirds of otosclerosis cases have a family history of hearing loss (3).

Three different treatment modalities have been defined for otosclerosis: wait - see, hearing aid, and stapes surgery. The effect of stapes surgery on conductive hearing loss due to otosclerosis is well known. Stapedectomy, defined by John Shea, has been replaced by stapedotomy over time. The risk of sensorineural hearing loss with stapedotomy is reported to be less (4-7).

Although some prognostic factors have been emphasized in the preoperative evaluation of otosclerosis, these factors are not clear as in tympanoplasty $(5,6)$. Surgical experience, patient characteristics and intra-operative findings have an important place among prognostic factors (8-10).

In our study, the functional results of patients who underwent stapedotomy with the diagnosis of otosclerosis were evaluated through an audiological perspective and a prognostic point of view. The effect of stapedotomy surgery on bone and air conduction hearing thresholds, and change in frequency-specific air-bone gap (ABG) were investigated.

\section{Methods}

\section{Patient Selection and Evaluation}

A retrospective analysis of 114 patients who underwent middle ear exploration with a preliminary diagnosis of otosclerosis between 2007 and 2013 was performed. Patients with tympanic membrane perforation or retraction and patients without intra-operative stapedial footplate fixation were excluded from the study. Stapedotomy was performed in all patients. Patients who had undergone revision surgery, ear surgery for another reason, and had juvenile otosclerosis were not included in the study. Age, gender, pre-operative and post-operative audiogram data, diameter of the prosthesis used during surgery, and hearing status of the other ear were recorded. The study was approved by the Local Ethics Committee of İstanbul Training and Research Hospital (513-25/07/2014).

The audiometric examinations (AC 40; Interacoustics A / S, Assens, Denmark), which were performed before the surgery and at least 1 year after surgery, were evaluated. In the pure tone audiometric examination, air conduction thresholds were examined at 250, 500, 1000, 2000, 4000 and $6000 \mathrm{~Hz}$ frequencies, and bone conduction thresholds at 500, 1000, 2000 and $4000 \mathrm{~Hz}$ frequencies. The pure tone average (PTA) values were calculated by taking the arithmetic average of both air and bone conduction thresholds at 500, 1000, 2000 and 4000 Hz. ABG at 500, 1000, 2000 and $4000 \mathrm{~Hz}$ was calculated by subtracting the bone conduction threshold value from the air conduction threshold value at these frequencies. The mean $A B G$ (mean $A B G$ ) value was calculated by taking the arithmetic average of the ABG values at four frequencies. The change in postoperative $A B G$ (gain) was determined by subtracting the postoperative $A B G$ value from preoperative $A B G$ value, and it was calculated separately for meanABG and for the four frequencies examined. The difference between pre-operative and postoperative bone conduction thresholds at 1000, 2000 and $4000 \mathrm{~Hz}$ were determined and the effect of surgery on bone conduction was evaluated. Positive value indicated improvement in bone conduction and negative value indicated damage in inner ear (11).

Speech reception threshold (SRT) and speech discrimination score (SDS) values in the speech audiometry were recorded. The post-operative changes in SRT and SDS values were determined.

The primary aim was to investigate post-operative $A B G$, the change in $A B G$ and changes in mean of bone conduction thresholds at 1000 , 2000 and $4000 \mathrm{~Hz}$. The secondary aim was to investigate the frequencyspecific changes in bone and air conduction thresholds, and changes in speech audiometry (SRT and SDS) values. The differences between the patients with 0.6 and $0.8 \mathrm{~mm}$ stapes prosthesis diameter were evaluated.

\section{Statistical Analysis}

SPSS 15.0 for Windows (IBM Corporation, Chicago, IL, USA) was used for statistical analysis. Descriptive statistics were expressed as number and percentage for categorical variables and mean \pm standard deviation (minimum-maximum) for numerical variables. The comparisons of non-normal distributed numerical variables between two independent groups were performed by using Mann-Whitney $U$ test. Dependent group comparisons were evaluated using the dependent sample t-test for normal distribution and Wilcoxon test for non-normal distribution. The relationships between the numerical variables were examined by Spearman's correlation analysis because of the non-parametric test condition. Statistical significance was accepted as $p<0.05$.

\section{Results}

Eighty-three patients (49 men and 34 women) who underwent stapes surgery were included in the study. Surgeries were performed by three different surgeons. The mean age of the patients was $41.3 \pm 11.11$ (minimum-maximum: 20-68) years. Hearing loss was accompanied by tinnitus in $49.4 \%$ of the patients, dizziness in $6 \%$ and pain in $2.4 \%$. The operated ear was on the left side in $47 \%$ and on the right side in $53 \%$. Hearing loss was detected in the other ear in $73.2 \%$ of the patients. 0.6 $\mathrm{mm}$ stapes prosthesis was used in 48 patients (58\%) and $0.8 \mathrm{~mm}$ stapes prosthesis was used in 35 patients (42\%). The main factor determining the diameter of the prosthesis was the size of the fenestration created at the base of the stapes.

The mean air conduction value was $56.1 \pm 9.9 \mathrm{~dB}$ hearing level $(\mathrm{HL})$ in the preoperative period, and $34.1 \pm 17.5 \mathrm{~dB} \mathrm{HL}$ in the postoperative period. The difference was statistically significant $(p<0.001)$. The reduction in air conduction thresholds at 250, 500, 1000, 2000, 4000 and $6000 \mathrm{~Hz}$ were similarly significant $(\mathrm{p}<0.05)$ (Table 1). The difference between the frequency-specific air conduction thresholds of different stapes prosthesis diameters was not significant. However, the PTA value of postoperative air conduction was significantly higher in patients with a $0.6 \mathrm{~mm}$ diameter stapes prosthesis $(p=0.042)$.

The mean bone conduction value was $18.1 \pm 7.3 \mathrm{~dB} \mathrm{HL}$ in the preoperative period, and $16.7 \pm 12.9 \mathrm{~dB} \mathrm{HL}$ in the postoperative period. 
Table 1. Preoperative and postoperative air conduction hearing thresholds

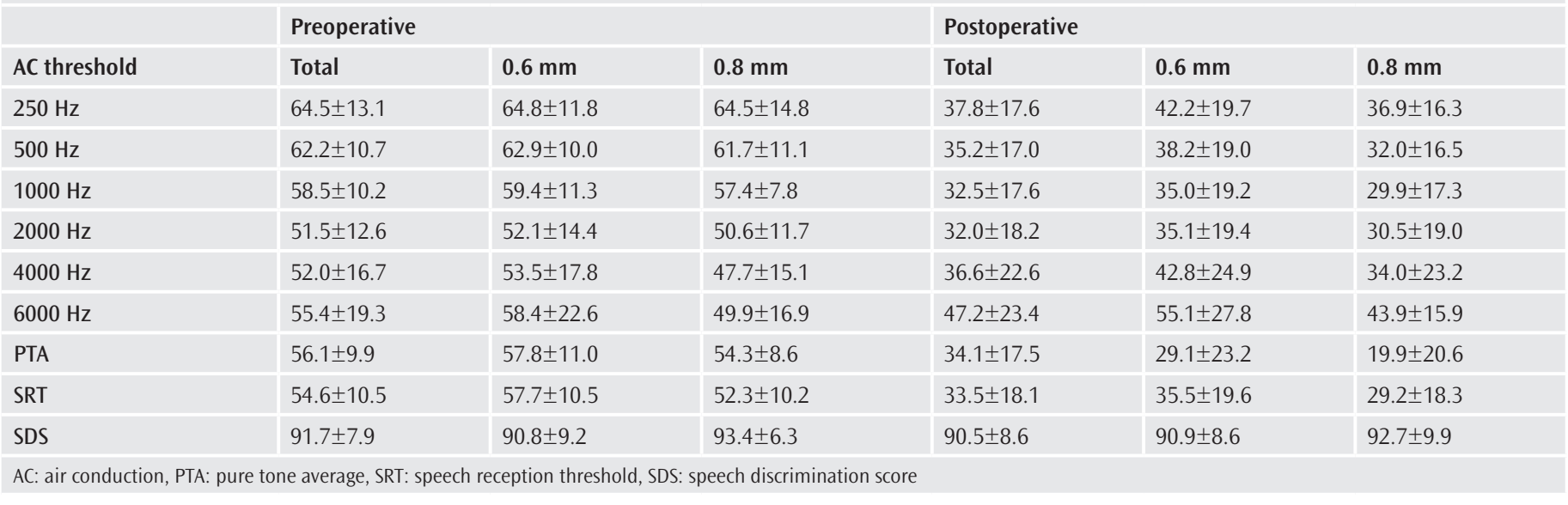

Table 2. Preoperative and post-operative bone conduction hearing thresholds

\begin{tabular}{|c|c|c|c|c|c|c|}
\hline \multirow[b]{2}{*}{ BC threshold } & \multicolumn{3}{|c|}{ Preoperative } & \multicolumn{3}{|c|}{ Postoperative } \\
\hline & Total & $0.6 \mathrm{~mm}$ & $0.8 \mathrm{~mm}$ & Total & $0.6 \mathrm{~mm}$ & $0.8 \mathrm{~mm}$ \\
\hline $500 \mathrm{~Hz}$ & $16.5 \pm 8.0$ & $17.9 \pm 9.8$ & $15.4 \pm 5.4$ & $14.9 \pm 12.9$ & $15.6 \pm 15.7$ & $11.7 \pm 10.1$ \\
\hline $2000 \mathrm{~Hz}$ & $21.5 \pm 10.4$ & $22.5 \pm 11.4$ & $19.3 \pm 8.4$ & $17.2 \pm 13.9$ & $17.6 \pm 17.3$ & $17.0 \pm 13.2$ \\
\hline $4000 \mathrm{~Hz}$ & $17.2 \pm 12.4$ & $18.0 \pm 13.4$ & $15.1 \pm 12.1$ & $19.1 \pm 15.7$ & $20.5 \pm 18.1$ & $17.0 \pm 17.0$ \\
\hline
\end{tabular}

Table 3. Air-bone gap values before and after otosclerosis surgery

\begin{tabular}{|l|l|l|l|l|l|}
\hline \multicolumn{2}{l}{ Preoperative } & \multicolumn{3}{l|}{ Postoperative } \\
\hline $\mathbf{A B G}$ & Total & $\mathbf{0 . 6} \mathbf{~ m m}$ & $\mathbf{0 . 8} \mathbf{~ m m}$ & Total & $\mathbf{0 . 6} \mathbf{~ m m ~}$ \\
\hline $\mathbf{5 0 0 ~ H z}$ & $45.8 \pm 11.3$ & $45.1 \pm 12.5$ & $46.5 \pm 11.3$ & $20.2 \pm 11.6$ & $17.4 \pm 14.4$ \\
\hline $\mathbf{1 0 0 0 ~ H z}$ & $41.3 \pm 9.0$ & $40.8 \pm 8.9$ & $42.2 \pm 8.0$ & $16.9 \pm 9.6$ & $14.4 \pm 11.6$ \\
\hline $\mathbf{2 0 0 0 ~ H z}$ & $30.1 \pm 8.7$ & $29.7 \pm 10.0$ & $31.0 \pm 8.2$ & $14.8 \pm 9.9$ & $13.5 \pm 11.1$ \\
\hline Mean ABG & $34.8 \pm 11.9$ & $35.3 \pm 13.1$ & $32.5 \pm 11.1$ & $17.4 \pm 12.3$ & $7.6 \pm 10.1$ \\
\hline
\end{tabular}

ABG: air-bone gap, mean ABG: mean air-bone gap

\begin{tabular}{l|l|l|l|}
\multirow{4}{l}{$\begin{array}{l}\text { Table 4. Distribution of air-bone gap according to different } \\
\text { frequencies }\end{array}$} & Total & $\mathbf{0 . 6} \mathbf{~ m m}$ & $\mathbf{0 . 8} \mathbf{~ m m}$ \\
\hline ABG change & $25.5 \pm 15.4$ & $27.9 \pm 18.3$ & $34.9 \pm 16.2$ \\
\hline $500 \mathrm{~Hz}$ & $24.5 \pm 13.6$ & $26.8 \pm 14.9$ & $32.4 \pm 13.6$ \\
\hline $1000 \mathrm{~Hz}$ & $15.3 \pm 13.6$ & $16.2 \pm 15.2$ & $23.3 \pm 13.1$ \\
\hline $2000 \mathrm{~Hz}$ & $17.3 \pm 14.9$ & $18.3 \pm 18.3$ & $22.8 \pm 14.0$ \\
\hline $4000 \mathrm{~Hz}$ & $20.7 \pm 11.4$ & $22.7 \pm 13.7$ & $28.3 \pm 11.6$ \\
\hline Mean ABG & \multicolumn{3}{|l|}{} \\
\hline ABG: air-bone gap, mean ABG: mean air-bone gap & \\
\hline
\end{tabular}

The difference was not statistically significant $(p=0.07)$. While the change in bone conduction thresholds at $500 \mathrm{~Hz}, 1000 \mathrm{~Hz}$ and $4000 \mathrm{~Hz}$ were not statistically significant, the change at $2000 \mathrm{~Hz}$ was statistically significant $(p=0.001)$. Bone conduction thresholds were not significantly different between patients with different stapes prosthesis diameters $(p>0.05)$ (Table 2).
The mean $\mathrm{ABG}$ value was $38 \pm 7.6 \mathrm{~dB} \mathrm{HL}$ in the preoperative period, and $17.3 \pm 9.2 \mathrm{~dB} H \mathrm{HL}$ in the postoperative period $(p<0.001)$. Mean $A B G$ and $A B G$ values at all frequencies showed a statistically significant decrease (Table 3). The ABG values at 2000 and $4000 \mathrm{~Hz}$ in the postoperative period and mean $A B G$ values were significantly higher in patients with a $0.6 \mathrm{~mm}$ stapes prosthesis diameter compared to patients with a $0.8 \mathrm{~mm}$ prosthesis diameter $(\mathrm{p}<0.05)$.

The mean ABG change was $20.7 \pm 11.4$. The highest ABG change was found at $500 \mathrm{~Hz}$ and the lowest value was at $2000 \mathrm{~Hz}$. The change at 2000 $\mathrm{Hz}$ was found to be significantly lower in patients with a $0.6 \mathrm{~mm}$ stapes prosthesis diameter compared to patients with a $0.8 \mathrm{~mm}$ prosthesis diameter $(p=0.029)$. Regarding ABG, there was no significant difference between the patients with different stapes prosthesis diameters, except at $2000 \mathrm{~Hz}$. The change in ABG is given in Table 4.

There was no statistically significant relationship between age, gender, and change in ABG ( $p>0.05)$. Preoperative bone conduction threshold 
values were significantly $(p<0.05)$ negatively correlated with ABG change at all frequencies, except $2000 \mathrm{~Hz}(p=0.092)$.

There was no statistically significant relationship between bone conduction at high frequency and age $(p=0.597)$ and gender $(p=0.985)$. This value was positive in 58 patients (70\%) and negative in 25 patients (30\%). Two patients with negative values were diagnosed with total hearing loss after surgery. This variable was positively correlated with bone conduction hearing thresholds and mean bone conduction threshold values at $500 \mathrm{~Hz}$ and $1000 \mathrm{~Hz}(p=0.011, p=0.004, p=0.010$, respectively). On the other hand, no significant relationship was found with bone conduction hearing thresholds at 2000 and $4000 \mathrm{~Hz}$ ( $p=0.098$ and $p=0.259$, respectively). The mean of bone conduction threshold change at high frequency was found to be $5.8 \mathrm{~dB} \mathrm{HL}$ in the $0.6 \mathrm{~mm}$ prosthesis diameter group, and $7.2 \mathrm{~dB} \mathrm{HL}$ in the $0.8 \mathrm{~mm}$ prosthesis diameter group $(p=0.64)$.

While the postoperative change in SRT was statistically significant $(p<0.001)$, there was no significant change in SDS $(p=0.43)$ (Table 1). There was a negative correlation between the change in SRT and bone conduction hearing threshold level at $4000 \mathrm{~Hz}(p=0.046)$, and positive correlation with air conduction hearing threshold levels at 500 and $1000 \mathrm{~Hz}(p=0.024$ and $p=0.005$, respectively). There was also a positive correlation between this change and $A B G$ at $1000 \mathrm{~Hz}(p=0.005)$. There was no statistically significant relationship between the change in SDS and the other parameters. There was also no statistically significant difference between SRT $(p=0.682)$ and SDS $(p=0.648)$ change in gender groups.

\section{Discussion}

Stapedotomy is known to cause gains in air conduction hearing thresholds in patients with otosclerosis. In our study, gain is obtained at all frequencies in the postoperative air conduction hearing threshold values compared to the preoperative values, while gain was achieved only at $2000 \mathrm{~Hz}$ in bone conduction. Both the significant gain in the bone conduction at $2000 \mathrm{~Hz}$ and the lower gain in the ABG at 2000 $\mathrm{Hz}$ compared to other frequencies are consistent with the principle of formation of the Carhart's notch. When the Carhart's notch was first described by Carhart (12) in 1950, it was reported as a worsening at the pure tone threshold of bone conduction at maximum $2000 \mathrm{~Hz}$ (500 to $4000 \mathrm{~Hz}$ ). Although the Carhart's notch formation mechanism, which was reviewed after that period, has not been fully elucidated, some studies have been reported to support the association with the resonance frequency of the ossicular chain (13-15). After a successful otosclerosis surgery, Carhart's notch disappears. Therefore, this is thought that bone conduction thresholds at $2000 \mathrm{~Hz}$ do not reflect the cochlear reserve.

In our study, a significant negative correlation was found between ABG gain and preoperative bone conduction hearing thresholds at all frequencies, except $2000 \mathrm{~Hz}$. In other words, preoperative bone conduction thresholds were determined as a prognostic factor affecting the gain in ABG. The data we have obtained suggest that the individuals who have better bone conduction thresholds will be more likely to have $A B G$ gain.

The highest gain in ABG was detected at $500 \mathrm{~Hz}$ and $1000 \mathrm{~Hz}$. When the preoperative $A B G$ values were examined, the highest values were found at 500 and $1000 \mathrm{~Hz}$ similarly. These data are interpreted as being compatible with the fact that otosclerosis causes more hearing loss at lower frequencies. Otosclerosis acts on the rigidity of middle ear and affects especially low frequencies. However, high frequencies are also affected in the presence of progressive disease (16). In the studies examining the relationship between $\mathrm{ABG}$ gain and age, Marchese et al. (3) reported low functional results at age 50 and older and Bittermann et al. (8) stated that ABG gain was advantageous in patients over 40 years of age. In our study, there was no relationship between ABG gain and age.

There was a statistically significant change between pre-and postoperative ABG values at all frequencies $(500,1000,2000$ and $4000 \mathrm{~Hz})$. The highest gain was achieved at $500 \mathrm{~Hz}$, while the lowest gain was at $2000 \mathrm{~Hz}$. In our study, a significant improvement was observed at all frequencies in postoperative air conduction hearing thresholds. Gerard et al. (5) and Meyer (17) reported that there might be no significant improvement at high frequencies due to the effect of cochlear otosclerosis. On the other hand, Ueda et al. (18) reported a significant ABG gain at 2000 and 4000 $\mathrm{Hz}$, and poor gain at higher frequencies and below $1000 \mathrm{~Hz}$.

Postoperative changes in the ossicular chain after a successful stapes surgery are known as overclosure (11). In case of a worsening in this value, which is calculated as the change in mean bone conduction threshold at 1000, 2000 and $4000 \mathrm{~Hz}$, a surgical damage to the cochlea can be interpreted (11). This change, calculated as negative in 30.1\% (25 patients) in our patient group, gives the rate of internal ear damage that occurred during or after surgery.

Conflicting findings have been obtained in studies on the effect of stapes prosthesis diameter on hearing gain in otosclerosis surgery. There are studies reporting that the prosthetic diameter does not have an effect on hearing gain, and there are studies reporting that largescale prostheses provide more gains at lower frequencies and smalldiameter prostheses at higher frequencies (19-23). In cases where small fenestration is made at the stapes base, the risk of internal ear damage and prosthesis migration is reported to be less (24). In our study, no significant difference was found between the bone conduction thresholds of groups with a 0.6 or $0.8 \mathrm{~mm}$ stapes prosthesis diameter. When the frequency-specific air conduction thresholds were examined, there was no significant difference between the two groups, while the mean air conduction was significantly higher in the patient group with $0.6 \mathrm{~mm}$ diameter prosthesis. The change in ABG was found to be significantly higher at only $2000 \mathrm{~Hz}$ in the $0.8 \mathrm{~mm}$ prosthesis diameter group. Postoperative ABG values were found to be significantly lower in the $0.8 \mathrm{~mm}$ prosthetic diameter group at 2000 and $4000 \mathrm{~Hz}$. The change in mean bone conduction at high frequency that is used to detect inner ear damage did not show a significant difference between the groups. These findings can be interpreted as partially better results with $0.8 \mathrm{~mm}$ stapes piston diameter.

\section{Conclusion}

In our study, gain was obtained at all frequencies in air conduction thresholds after stapedotomy. The significant gain in the bone conduction thresholds at $2000 \mathrm{~Hz}$ reflects the Carhart's phenomenon. Otosclerosis is associated with conductive hearing loss at low frequencies, especially 
at the beginning. Observing the highest change at $500 \mathrm{~Hz}$ is consistent with this fact. In our study, it was found that ABG gain increased with decreasing preoperative bone conduction threshold. It was determined that the postoperative $A B G$ was less with $0.8 \mathrm{~mm}$ stapes prosthesis diameter, especially at 2000 and $4000 \mathrm{~Hz}$. There was no significant difference in hearing gain between patients with 0.6 and $0.8 \mathrm{~mm}$ stapes prosthesis diameter.

Ethics Committee Approval: İstanbul Training and Research Hospital (513-25/07/2014).

Informed Consent: Retrospective study.

Peer-review: Externally peer-reviewed.

Author Contributions: Concept - D.T.E., A.G.Y; Design - D.T.E., M.F.Y.A.; Supervision - Ö.Y., D.T.E., M.F.Y.A.; Data Collection and/or Processing - A.G.Y., M.F.Y.A., D.T.E.; Analysis and/or Interpretation - Ö.Y., D.T.E..; Literature Search - D.T.E., M.F.Y.A., A.G.Y., Ö.Y.; Writing Manuscript D.T.E., A.G.Y.; Critical Review - Ö.Y., M.F.Y.A.

Conflict of Interest: No conflict of interest was declared by the authors.

Financial Disclosure: The authors declared that this study received no financial support.

\section{References}

1. Koopmann M, Weiss D, Savvas E, Rudack C, Stenner M. Outcome measures in stapes surgery: postoperative results are independent from preoperative parameters. Eur Arch Otorhinolaryngol 2015; 272: 2175-81.

2. Caylakli F, Yavuz H, Yilmazer C, Yilmaz I, Ozluoglu LN. Effect of preoperative hearing level on success of stapes surgery. Otolaryngol Head Neck Surg 2009; 141: $12-5$.

3. Marchese MR, Conti G, Cianfrone F, Scorpecci A, Fetoni AR, Paludetti G. Predictive role of audiological and clinical features for functional results after stapedotomy. Audiol Neurootol 2009; 14: 279-85.

4. Vincent R, Sperling NM, Oates J, Jindal M. Surgical findings and long-term hearing results in 3,050 stapedotomies for primary otosclerosis: a prospective study with the otology-neurotology database. Otol Neurotol 2006; 27: p.25-47.

5. Gerard JM, Serry P, Gersdorff MC. Outcome and lack of prognostic factors in stapes surgery. Otol Neurotol 2008; 29: 290-4.

6. Fisch U. Stapedotomy versus stapedectomy. Otol Neurotol 2009; 30: 1166-7.

7. Spandow 0 , Söderberg 0 , Bohlin L. Long-term results in otosclerotic patients operated by stapedectomy or stapedotomy. Scand Audiol 2000; 29: 186-90.

8. Bittermann AJ, Rovers MM, Tange RA, Vincent R, Dreschler WA, Grolman W. Primary stapes surgery in patients with otosclerosis: prediction of postoperative outcome. Arch Otolaryngol Head Neck Surg 2011; 137: 780-4.
9. Kisilevsky V, Bailie NA, Halik JJ. Bilateral hearing results of 751 unilateral stapedotomies evaluated with the Glasgow benefitplot. J Laryngol Otol 2010; 124: 482-9.

10. de Bruijn AJ, Tange RA, Dreschler WA. Efficacy of evaluation of audiometric results after stapes surgery in otosclerosis. I. The effects of using different audiologic parameters and criteria on success rates. Otolaryngol Head Neck Surg 2001; 124: 76-83.

11. Committee on Hearing and Equilibrium guidelines for the evaluation of results of treatment of conductive hearingloss. American Academy of Otolaryngology-Head and Neck Surgery Foundation, Inc. Otolaryngol Head NeckSurg 1995; 113: 186-7.

12. Carhart R. The clinical application of bone conduction audiometry. Arch Otolaryngol 1950; 51: 798-808.

13. Homma K, Du Y, Shizmu Y, Puria S. Ossicular resonance modes of the human middle ear for bone and air conduction. Journal of the Acoustical Society of America 2009; 125: 968-79.

14. Tondorf J. A new concept of bone conduction. Arch Otolaryngol 1968; 87: 595-600.

15. Perez R, de Almeida J, Nedzelski JM, Chen JM. Variations in the "Carhart notch" and overclosure after laser-assisted stapedotomy in otosclerosis. Otol Neurotol 2009; 30: 1033-6.

16. Saraç S, Topal Ö, Bajin D. Otoskleroz. In: Koç C, editor. Kulak Burun Boğaz Hastalıkları ve Baş-Boyun Cerrahisi. İkinci baskı. Ankara, Güneș Kitabevi; 2013. p.151-8.

17. Meyer SE. Theeffect of stapes surgery on high frequency hearing in patients with otosclerosis. Am J Otol 1999; 20: 36-40.

18. Ueda H, Miyazawa T, Asahi K, Yanagita N. Factors affecting hearing results after stapes surgery. J Laryngol Otol 1999; 113: 417-21.

19. Fucci MJ, Lippy WH, Schuring AG, Rizer FM. Prosthesis size in stapedectomy Otolaryngol Head Neck Surg 1998; 118: 1-5.

20. Gristwood RE, Venables WN. Effects of fenestra size and piston diameter on the outcome of stapes surgery for clinical otosclerosis. Ann Otol Rhinol Laryngol 2011; 120: 363-71.

21. Sennaroğlu L, Unal OF, Sennaroğlu G, Gürsel B, Belgin E. Effect of teflon piston diameter on hearing result after stapedotomy. Otolaryngol Head Neck Surg 2001; 124: 279-81.

22. Smyth GD, Hassard TH. Eighteen years experience in stapedectomy. The case for the small fenestra operation. Ann Otol Rhinol Laryngol Suppl 1978; 87: 3-36.

23. Shabana YK, Ghonim MR, Pedersen CB. Stapedotomy: does prosthesis diameter affect outcome? Clin Otolaryngol Allied Sci 1999; 24: 91-4.

24. Herzog JA. 0.4 mm stapedotomy: a consistent technique for otosclerosis. Am J Otol 1991; 12: 16-9. 